\title{
Concept map to visualize opposite perspectives of Rapa Nui history as a whole
}

\begin{abstract}
This work presents contrasting views on the socio-environmental history of the Rapa Nui. The dominant point of view argues for the occurrence of a cultural "ecocide" caused by the environmental degradation of the Easter Island environment. The opposite school that suggests that introduction of diseases and practice of slavery by foreign visitors was responsible for societal collapse. This integrative view is a product of a concept map developed in Cmap Tools software, based on literature review and field work during 2015. The concept map identified the crucial elements in causal chains, corresponding to the turning points of the argumentative chains, from one school of thoughts to the other one. The interdependence among the two schools of thoughts were demonstrated by different causal chains (highlighted by the use of different colors in the connection lines) sharing the same concepts or elements in the system (the turning points). These turning points highlighted in the concept map, were: eating palm fruits by rodents, decrease of palm trees, transportation of statues (moai), production of canoes, getting firewood and landscape pattern. This work demonstrated how concept maps can contribute to a more comprehensive understanding of the Rapa Nui history and it identified the key processes that drive the interpretative choices for one school of thought or another. As a result, it can be noted that the concept map can effectively address what are the key processes that investigations should focus on to advance our understanding of the Rapa Nui prehistory.
\end{abstract}

Keywords: Rapa nui, Easter island, Conceptual modeling, Concept map, Systems thinking, Interdisciplinary, Integrative view, Ecocide
Volume I Issue 5 - 2017

\section{Carlos Hiroo Saito}

Department of Ecology/Institute of Biological Sciences and Center for Sustainable Development, University of Brasilia, Brazil

Correspondence: Carlos Hiroo Saito, Department of Ecology/ Institute of Biological Sciences and Center for Sustainable Development, University of Brasilia, Brazil, Tel +55-6I-31073002,Email carlos.h.saito@hotmail.com

Received: April II, 2017| Published: August 28, 2017
Abbreviations: CE, common era; Ma, mega-annum; m, meters; OHD, obsidian hydration dating

\section{Introduction}

Environmental Sciences, as an emerging academic area, calls for an interdisciplinary approach seeking an integrated view, within a conceptual model capable of dealing with a complex web of knowledge. However, it is not easy to promote an analysis within this interdisciplinary approach, because we are just heirs of a disciplinary formation. More than that, we often find it difficult to fully understand the chain of concepts and interactions in our own field, in enough detail which leads to establishing interdisciplinary bridges. Within our disciplinary domains, we fail to pay attention to some concepts and many descriptions of basic processes, precisely because they are basic, current and supposedly easily understood according to our background formation. This can make our scientific communication and scientific literacy work a failure, as people can learn issues without a complete understanding, with lot of misunderstandings and disconnected pathways. One promising way to avoid these glitches resides in the use of conceptual modeling tools supported by graphic resources such as concept maps. There are also situations in which different opinions and paths of reasoning's coexist and people can find it difficult to understand where is the source of the divergence.

Therefore, the objective of the present work is to present a concept map that describes in a unique model the different schools of thought about the prehistory of Rapa Nui. The first and dominant idea, is the "ecocide" process of environmental collapse experienced in the past on Easter Island. The second is the counter-argument view that there would have been genocide of the native Rapanui people by foreign visitors (instead of ecocide) and that the Rapa Nui economy had been revamped and was sustainable up to and past European contact. The model we are presenting will help readers to identify the intersections of the different chains of thought about the Rapa Nui prehistoric socioenvironmental processes in a systemic manner. In this concept map, it is sought to interconnect the ecological and social aspects based on the literature to deal with the interactions among environment-cultureland use issues. Also, based on the concept map, it is shown an attempt to analyze how the different socio-environmental processes and basic concepts of each school of thought are related to the (un)sustainability of social practices. Finally, it analyzes how these processes can be better understood through concept maps, with emphasis on feedback cycles based on a systemic viewpoint. For this discussion, we will adopt Rapa Nui to refer to the Island and Rapanui to its people.

\section{Methodological procedures}

In order to understand the social and environmental processes involved in the history of Rapa Nui, a literature review and field work was completed in 2015 to support conceptual modeling. Several authors and their published works were considered as key references, among others: Katherine Pease Routledge, Alfred Métraux, Catherine Orliac, Rosalind L Hunter-Anderson, Joan A Wozniak, Benny Peiser, Jared Diamond, Terry L Hunt and Carl P Lipo, John R Flenley and Paul G Bahn, Barzin Pakandam andreas Mieth and Hans-Rudolf Bork and Christopher Stevenson, et al., After exhaustive reading of these texts, a concept map was constructed from the information contained therein. The concept maps were produced in CMAP-tools software. 
The concept map, as diagrams capable of indicating relations between concepts or between words that we use to represent concepts is recognized as a tool capable of bringing together theories, concepts and consequently common objectives of these different areas of knowledge. ${ }^{1}$ Concepts whose relations are visualized in concept maps represent a perceived pattern (regularity) in events or objects or records of events or objects, designated by label (denominating term). It is believed that the knowledgeable potential described for concept maps is due to facilitated mediation both in creating a common understanding and in reducing communication errors among individuals through an entire sight of the meanings. ${ }^{2}$

The construction of concept maps allows us to organize the understanding of a situation portrayed by the one who created it. To do so, it is necessary to determine the parts of the system, to choose the relations of interest among these parts and specify the mechanisms by which the parts interact with each other. It is also necessary to identify the missing information and finally, exploring their behavior of the components if it will be used for simulation. It will present a hierarchical structure, mainly by the vertical stratification of main concepts and other secondary concepts associated to them. It is believed that the construction process can be as enlightening (for those who develop the concept map) as the model itself. This is possible because the construction process reveals what we know and what we do not know about the connections and it identifies the gaps in both concepts and explanations of causal relationships. ${ }^{1}$ The concept maps demand not only the exteriorization of the thought by the one who elaborates the concept map, but in doing this exteriorization, it leads the developers to specify organize and structure their own knowledge. In sum, concept interrelatedness is an essential property of knowledge. ${ }^{3}$

For this reason, Joseph D Novak \& Alberto J Cañas ${ }^{2}$ argue that the first step relative to the construction of concept maps lays in the necessity to define the knowledge area and the establishment of a focusing question, which must be answered by information to be described. For these authors, the focusing question requires an explanation, far beyond a simple description or classification. ${ }^{2}$ In the present case, it is a matter of understanding the complex dynamics of interactions that explain the collapse of the Rapa Nui civilization.

Another aspect to be highlighted is the strong contribution of the concept maps to the development of an interdisciplinary knowledge. ${ }^{4,5}$ In this case, it is possible to place both ecological processes and social processes on the same concept map and show their mutual interdependencies. It is important to note that for the purposes of this paper, the analysis provided by concept maps should be effective at the landscape scale and recognize it's multiple and complex scale interactions. ${ }^{6}$

\section{Rapa nui}

Rapa Nui (also known as Easter Island) was the result of numerous volcanic events, which created topographic landforms up to $507 \mathrm{~m}$ in elevation (e.g. Maunga Teravaka, an inactive volcano in the northern part of the island). Luigina Vezzoli \& Valeiro Acocella ${ }^{7}$ based on new field and petrochemical data, established two periods for the island evolution varying between $0.78-0.11 \mathrm{Ma}^{7}$ The total island area is of $180 \mathrm{~km}^{2}$, triangular in shape, with sides of $16 \times 18 \times 24 \mathrm{~km}$ and a perimeter of $56 \mathrm{~km}^{8}{ }^{8}$ Three volcanoes are located at the vertices and encompass the intervening lowlands. The island presents a weak annual cycle of monthly mean temperature (between 18.0 and $23.8^{\circ} \mathrm{C}$ ) and annual rainfall varies from 630 to $2100 \mathrm{~mm}$ depending on the locality around the island. ${ }^{9,10}$ Winds are a near constant occurrence and are present throughout the day. The southeasterly trade winds predominate from September to June and the northeasterly trade winds occur during July and August ${ }^{11}$ There are no permanent streams or rivers on the island but there are three freshwater crater lakes (known as rano), at Rano Kau, Rano Raraku and Rano Aroi and a spring (puna) near Puna Pau. ${ }^{12}$ Due to its volcanic origin, the island has plenty of volcanic rocks such as basalt, which were intensively weathered, partly eroded and transported down slope during the younger Quaternary. ${ }^{13}$ Routledge's observations complement the island landscape description: "There are no ravines, no wooded precipices, no inaccessible heights, but round the whole coast erosion is at work, with the result that, while on the land side the slopes of all these three mountains are gradual, on the sea side that is, in portions of the north, east and west coast is respectively they have been worn back by the power of the waves into imposing cliffs". ${ }^{14}$

The island is situated on the eastern tip of the great Polynesian triangle and it is considered the furthest point on the planet in terms of connectivity with other areas and thus considered most isolated. It is situated about 3,700 km from the South American coast. The name Rapa Nui means "Big Island," reinforcing the Polynesian origin of its inhabitants, who are believed to have reached the island around the year 1,200 CE, based on radiocarbon dating conducted by Terry L Hunt \& Carl P Lipo. ${ }^{15}$ John R Flenley \& Paul G Bahn ${ }^{16}$ questioned this settlement period ${ }^{16}$ arguing that dated changes in tree pollen, indicative of deforestation ${ }^{17}$ suggested colonization of the island around $1000 \mathrm{BP}$ (or $950 \mathrm{CE}$ ).

Rapa Nui society was structured as a hierarchical chiefdom, headed by the chiefly families and a supporting religious aristocracy, whose positions were based on the descendants of divine origin. ${ }^{18}$ The monumental constructions devoted to the worship of the ancestors of each lineage represented the visible evidence of the genealogical link to a specific territory. The construction of the statues also legitimated the dominance of these same territories: the statues (moai) (images of the deceased ancestors) positioned on platforms made of low and wide stone $(a h u)$ and both were placed on the coast. It is important to say that the coast was the center of this political power and from which they controlled the territories (kainga) that extended into the interior of the island.

It is generally believed that the first inhabitants of the island found a rich, densely vegetated, palm woodland, unlike the grass-dominated landscape found by Europeans in the $18^{\text {th }}$ century. ${ }^{19}$ An anthracological study showed the presence of fourteen botanical genera and fifteen woody species to which are added six other unidentified taxa. ${ }^{20}$ According to the dominant view, the inhabitants exploited the natural resources to exhaustion (it is stated they unceasingly continued to fell trees until all of them were wiped out), causing the collapse of civilization an ecological collapse know as ecocide..$^{21,22}$

Also contributing to the deforestation was the presence of introduced Polynesian rats, which would have gnawed away seeds burrowed into the nut in order to eat the kernel thus preventing palm growth. Pacific rats (Rattus exulans), recognized as an invasive species and also contributed to the disappearance of native fauna, especially seabirds, by eating the bird's eggs or by direct preying on the birds. ${ }^{23-26}$ 
There is a disagreement as to the very description of collapse Collapse means that a system (in this case, the island ecosystem) loses its capability of self-maintenance, which leads to non-recoverable environmental degradation. The question is the cause of the collapse: some believe that the local people themselves would have cut down the last palm tree for the use of its wood and this intentional deforestation was the beginning of progressive soil degradation, lower food production, famine, social conflicts, cultural instability, wars and population decline. Considering that the collapse would have been caused by the Rapa Nui, this school of thought considers that it would be an example of ecocide a self inflicted socio-environmental collapse. Jared Diamond speculated what the native, who would have cut the last palm tree, said at that very moment. ${ }^{21} \mathrm{He}$ believed that large scale deforestation began around the year $900 \mathrm{CE}$ and was completed by 1722 , when the navigator Jacob Roggeveen arrived on the island and did not see any tree greater than 10 feet tall. Hans-Rudolf Bork \& Andreas Mieth ${ }^{27}$ believed that the clearance of the palm forest was intensified from about cal. CE 800 until cal. CE 1300/1500. ${ }^{27}$ Mark Horrocks \& Joan A Wozniak ${ }^{28}$ argues that the radiocarbon chronology suggested that clearance occurred from c. 750 to $1150 \mathrm{CE}$ (1200 to 800 year BP), with total deforestation concluded by c. 1450 CE (500 year BP). ${ }^{28}$

Christopher Stevenson and colleagues argued that the process of landscape transformation on Rapa Nui Island was not linear and unidirectional towards the catastrophe as Diamond and others argued. In their recent study, these researchers argued that the climate conditions on the island showed variations with periodic droughts, based on analysis of land use by obsidian hydration dating (OHD) of tools and flakes. They said that if similar droughts existed in earlier time before the arrival of the Europeans, such climatic events would have subjected their population and their production to difficulties. ${ }^{9}$ Soil and climatic conditions in their study area SA1 near the northwest (dry) coast and study area SA2 in the Maunga Terevaka (humid and infertile) would have reduced agricultural production substantially by the time of contact with Europeans. On the other hand, in study area SA3 (within the island, on the northeast coast, west of Anakena beach), with adequate rainfall and fertile soil, land use was relatively intense from the late $1600 \mathrm{~s}$ until after the 1800s. These authors agreed with the existence of declines in agricultural production and reductions in the intensity of land use in the dry northwest section of Rapa Nui and the region of nutrient-leached soils in upland areas, before European contact. They hypothesize that this decline, although localized, may have triggered social disruptions over land tenure and may have increased land pressure in other parts of the island as land use was renegotiated. Nevertheless, they disagreed with the notion of a broad or total collapse of the Rapanui before contact with the Europeans. ${ }^{9}$

Burning can also be added as a reason for Rapa Nui landscape transformation: Forest clearance can be associated with the necessity for firewood used in daily activities. This idea was contested by Rosalind L Hunter Anderson who said that no palm wood has been identified as household fuel and that this was in tune with practices elsewhere in the Pacific, where people used to have dry husks and shells of coconuts, as well as dead branches and rotten tree trunks or a variety of trees as the usual cooking fuels. ${ }^{29}$ Additionally, Jennifer Huebert, Melinda Allen \& Rod Wallace, ${ }^{30}$ based on the work of Orliac, ${ }^{31}$ said that there are records of the increased use of non-woody fuels such as grasses and twigs over time as woody vegetation declined on Rapa Nui island. Nevertheless, even limited burning can result in uncontrolled fires. Daniel Mann and colleagues state that the island showed no history of frequent fire disturbance but and due to the island's small size, high winds and seasonal droughts, combined with a topography without natural firebreaks, the island terrain probably suffered rapid burnings. ${ }^{32}$

Benny Peiser ${ }^{33}$ seeks to explain the root of these differences. According to this author, the dominant view whose exponent is Jared Diamond, argues that in the few centuries after the island was colonized, the Rapanui people themselves would have destroyed their forest, degraded the soil of the island, eliminated its plants and brought its fauna to extinction. As a result of this self-inflicted environmental devastation, the complex society would have disintegrated by itself from civil war and cannibalism. From this perspective, when Europeans re-discovered the island in the $18^{\text {th }}$ century, they would have already found a broken society and a remnant population full of deprivations that lingered among the ruins of their past..$^{33}$ For this author, Diamond's line of reasoning and his followers are based on the idea that the decline and socio-environmental collapse of Rapa Nui Island would have occurred before Europeans arrived. This line of reasoning, which illustrates the theory of ecocide, is denied by Terry L Hunt \& Carl P Lipo ${ }^{34}$ who addressed that a real genocide would have destroyed the indigenous population of Rapanui and its culture and they said that this genocide was perpetrated by slave traders, whalers and settlers who removed persons and also introduced European pathogens. ${ }^{33,34}$ A native Rapanui said that "Peruvian slave raids from around 1859 to 1864 abducted several hundred Rapanui, including the Ariki (individual of high rank) and nearly all of the high chiefs". ${ }^{35}$

\section{What concept maps can show us?}

The concept map is a structured model in a well-organized format which, in this work, assists readers in their understanding of disputed issues about the Rapa Nui prehistoric socio-environmental processes. The aim of the work is neither to make an exhaustive analysis of scientific findings nor to solve doubts and divergences among scientists. Also, there is no intention to take sides in favor of one school of thought over the other. Nevertheless, the concept map can make explicit the opposing or conflicting visions about these prehistoric socio-environmental processes, showing the argumentative logic of each school of thought and how the reasoning processes diverge. Because it can address the key features of an argument's viewpoint, this work can help identify new research routes that will clarify and solve divergences. This work can thus demonstrate the didactic potential that the concept map has, especially by demonstrating the chains of interdependence between concepts and the logic structuring elements of these concepts, from both schools of thought. In this sense, the concept map presented here can be considered an expansion of Flenley \& Bahn' ${ }^{24}$ original attempt to describe the network relationships through a chart (Figure 1). ${ }^{24}$

Figure 1 is taken as a departure point to in the debate between dominant and counter-argument views. The concept map sought to record the wealth of information brought from different researchers and from different areas of knowledge (Figure 2). The black lines portray the chain of interdependencies according to the dominant theory of ecocide. The red lines portray alternative views to the specific parts of the causal network that end up questioning the dominant theory.

The concept maps help us to understand important elements such as the cycles of feedback, in some specific contexts of the complex web of socio-environmental processes. That is why concept maps allow 
the development of a systemic reasoning ${ }^{36,37}$ in this case, for Rapa Nui prehistory. For example, the palm tree Paschalococos disperta occupies a prominent position on the concept map and participates in more than one process cycle. It is also part of the Pacific rat's cycle and part of the canoe production cycle, as much as it is part of the statue moving (transportation) cycle and the production of firewood cycle. All of them have two possible cycle routes, a blue route (dominant view) and a red route (counter-argument view).

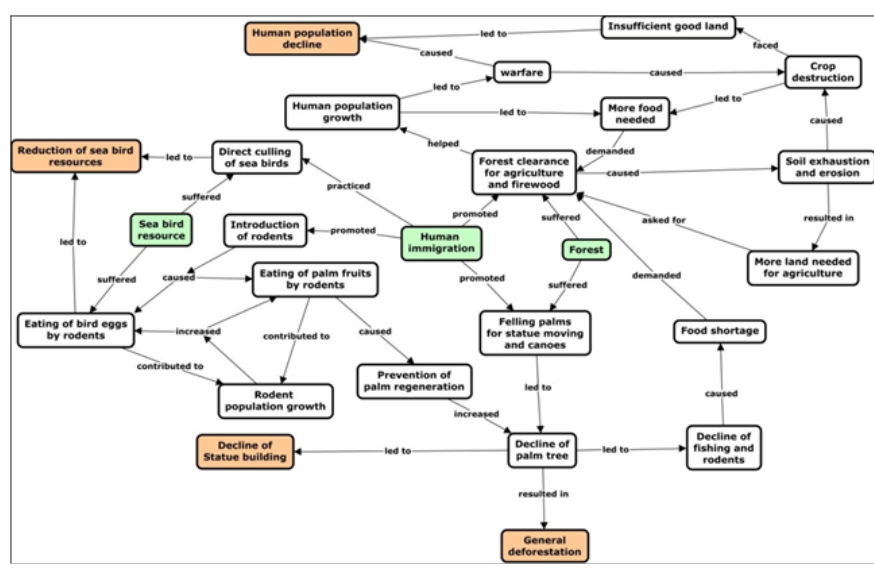

Figure I Flenley and Bahn's ${ }^{24}$ network relationship chart modified to a concept map. The green central boxes represent the initial conditions, the white boxes represent the transitional stages and the orange boxes represent the final results.

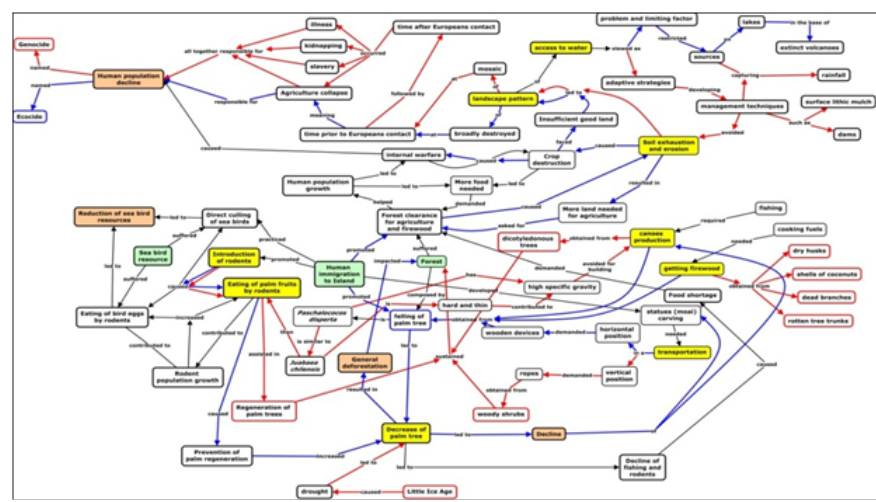

Figure 2 Concept map representing knowledge complexity of the Rapa Nui history.

The palm tree and the Pacific rats (Rattus exulans) are connected in a cycle of processes that is represented in the concept map of Figure 3. The rat would have gnawed on the seeds and sprouts of the Easter Island palm (Paschalococos disperta), damaging its regeneration. ${ }^{16,23,24}$ The visualization of this cycle is shown in Figure 4. The concept map also shows an alternative path in red lines. Rosalind L HunterAnderson argued that the Pacific rats, in opposition to harming the regeneration of palm trees, would have helped in their multiplication. She stated that if the palms of Easter Island (Paschalococos disperta) were really similar to the Chilean palm (Jubaea chilensis), then the Polynesian rats would have assisted in its regeneration and would not have prevented it. ${ }^{29,38}$ Pacific rats can be argued against and in favor of ecocide theory, depending if one consider its introduction a matter of human impacts and the disturbance caused by this small rodent credited to part of self destruction or not. Hunter \& Lipo $^{39}$ seems to argue that rat impacts, as much as natural fire impacts, are uncontrolled negative disturbances that contradicts the ecocide argument where local people deliberately destroyed their environment. ${ }^{39}$ That is why the Pacific rat's processes are colored with both red and blue colors, representing the two schools of thought.

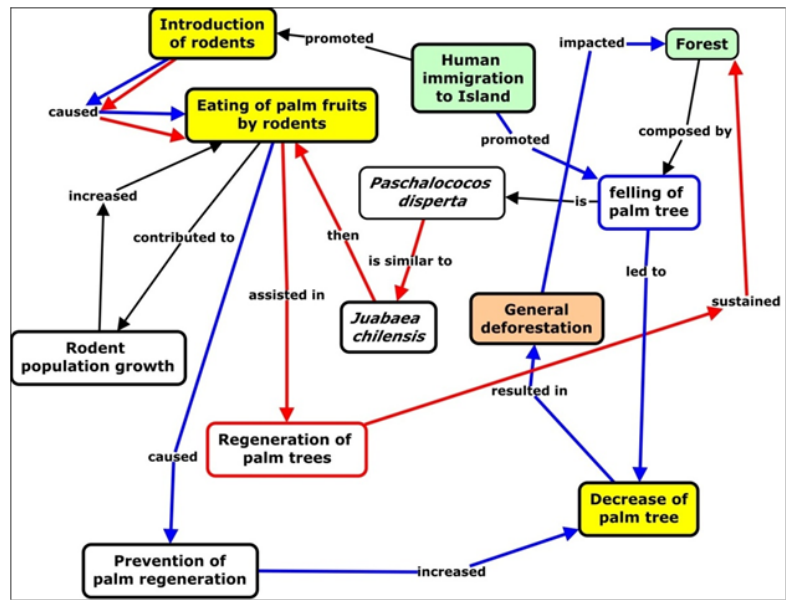

Figure 3 Focus on the part of the concept map relative to the palm tree and the Pacific rat's interaction.

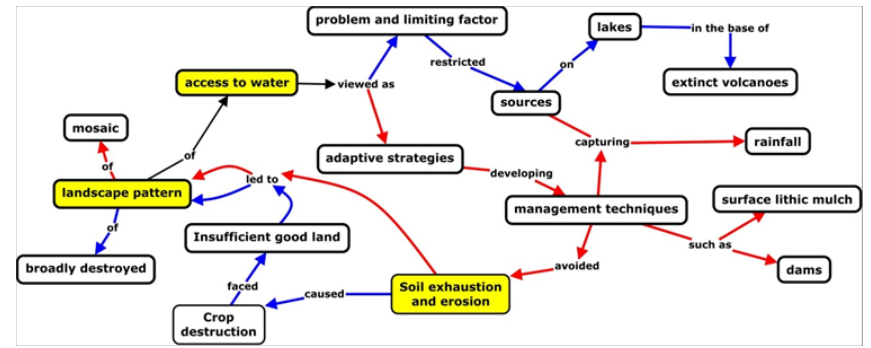

Figure 4 Focus on the part of the concept map relative to the access to fresh water

The regeneration of palm tree would have also been hampered by the fact that native Rapanui used to cut the palm, just when the trunk is formed (at 25-30 years of age) and before the reproductive age (around 50 years of age) when it tended to lose biomass and decrease its diameter, feeding back the process of loss of woody vegetation cover. ${ }^{40-42}$ The dominant view believes that this process triggered the loss of wood, both for the construction of larger canoes that allowed the Rapa Nui to fish in the open ocean (ensuring a source of protein), as well as for transportation and erection of the moai. According to this point of view, it is believed that by the time the Rapanui experienced overpopulation, few large trees remained, making it impossible to build canoes capable of long distance travel. ${ }^{23}$ Although fibrous trunk of palms can be seen considered unsuited for canoes, canoes made by the tough outer bark (pericarp) of Jubaea chilensis were described by Robert E Gurley \& William Liller ${ }^{43}$ as capable tof withstanding much physical abuse, because the pericarp was unusually dense (varying from 1300 to $1640 \mathrm{~kg} / \mathrm{m}){ }^{43}$

In the case of the dominant idea, it includes, besides the Pacific rats, wood, deforestation, scarcity (of food, water and resources as a consequence of deforestation), a socio-environmental collapse. The collapse phenomenon includes the end of moai construction activities, both due to the scarcity of wood that compromised the transport and erection of the statues. Additionally, it is shown that this termination of moai construction was due to the increasing difficulties in sustaining a class of artisans with food and benefits in times of crisis and scarcity, according to comments made by Barzin Pakandam..$^{23}$ 
It is highly likely that the availability of fresh water was limited on Rapa Nui. Barzin Pakandam ${ }^{23}$ states that the fresh water supply for agriculture and consumption was available in lakes found in the bottom of three extinct volcanoes. ${ }^{23}$ This author also notes that these fresh water supplies were limited and Rapanui had to rely on captured rainwater as a source for water. Candance L Gossen \& Christopher Stevenson $^{44}$ affirmed that Rapanui developed a set of agricultural innovations to counteract the effects of moisture loss, which could be evidence for a response to the impacts of deforestation and rainfall variability on the productive potential of the agricultural system. ${ }^{44}$ According to these authors, these developments included "the use of a surface lithic mulch to facilitate water permeability and reduce evaporation, rock placement within gardens as protection from wind and garden placement within protected environments at the base of slopes that benefited from surface water runoff". ${ }^{44}$ Joan A Wozniak ${ }^{45}$ remarked that "on Easter Island the lithic mulch layer covering prehistoric gardens is generally a $20-40 \mathrm{~cm}$ thick surface layer of small rocks over an anthropogenic (plaggen) soil layer that is 30 to $50 \mathrm{~cm}$ deep" ${ }^{45}$ Lightfoot referred to lithic mulch as that practice involving the use of pebbles, gravel, stones, volcanic ash and cinder or other lithic materials, which can advance germination, growth and maturation of crops by the augmentation of moisture and control of weeds and temperature. ${ }^{46}$ But due to the great efforts of ancient agriculturalists "to remove the stones from the ground, to pull up the long rooted weeds which cover it, then to loosen the soil, to build mounds and finally to cover the young plants with grass" ${ }^{47}$ it is said that Rapanui do not cultivate large areas.

The main agricultural production in Rapa Nui Island relied on sweet potato (Ipomoea batatas), dry land taro (Colocasia esculenta), yam (Dioscorea spp.) and ti (Cordyline spp.). In our field trip, native Rapanui mentioned the first two of the list. Another strategy to confront water scarcity was indicated by Burkhard Vogt and Johannes Moser who have documented how natural ravines were anthropogenically transformed by the building of stone and earth terraces across gullies to function as a dam. Additionally, during our field trip, native Rapanui showed us the presence of water in caves and the phenomena of water emergence from ground near the seashore during low-tide periods. Similarly, Metraux ${ }^{47}$ found that "Along the shore, where the coast is low, natives dug reservoirs (puna) which impounded rain water and perhaps some fresh water springs. A deep ditch, between 2 and 3 meters deep, is dug near the shore. The seaward, lateral sides are perpendicular and lined with stones perfectly fitted. The landward side slopes at an angle of 45 degrees to the base of the opposite wall and is paved with boulders. After a rain the running water is led to interior of the basin where at the same time water from the underground water body collects". He continued by remarking that "in a few places there are springs, holes among the rocks into which water percolates. Ruins of ancient settlements are always thick around water holes". All of these descriptions of strategies indicates that although water scarcity was a potential problem for survival, adaptive initiatives of the Rapa Nui allowed the long settlement of Rapa Nui ${ }^{48}$ (Figure 4).

The palm tree of Rapa Nui Island contributes to another chain of causal processes. It would have been gradually replaced by herbaceous vegetation, which then gave a new configuration to the previously densely palm covered landscape. Grasses have a higher propensity to burn, which aggravated the degradation of the soil surface layer, previously protected from the processes of weathering, laterization and laminar erosion by tree and shrub cover. Nevertheless grass cover on prehistoric Rapa Nui was a non-oily crump grass, different from introduced invasive alien species of present days, grasses in general are more likely to burn because immediate weather conditions more readily affect the amount of moisture in thinner fuels such as little bluestem and other grassland. ${ }^{49-50}$ Thus, the cycle of soil physical loss and also the loss of fertility, was accentuated, which led to an overall lower quality of soil, feeding back on a downward curve of food production and environmental collapse. ${ }^{23}$

In this respect, there is the idea that the degradation process on Rapa Nui has become irreversible, leading to an ecocide promoted by the Rapanui themselves. The concept of ecocide is highlighted in the concept map. One of the main chain of ideas supporting this point of view is the necessity of wood to horizontally transport of statues using wooden devices. This was questioned by Lipo et al. ${ }^{51}$ who demonstrated that there was no need of palm tree cutting for statues production and transportation, because statues stood up and "walked" to their final destinations in a vertical position ${ }^{51}$ (Figure 5). Lipo and colleagues's idea is in accordance to oral tradition, which explains that statues were rocked from side to side, moving it forward in a step-by-step manner, just like you would do to move a refrigerator in your kitchen. For this type of transport no wood would be required only ropes. They said that a woody shrub (Triumfetta semitrioba) that grows in disturbed habitats was abundant and it constituted the main material for ropes. Field research addressed to the same perspective, once there were found rope marks on the moai's neck and native Rapanui presented the same story of "walking statues" (Figure 6).

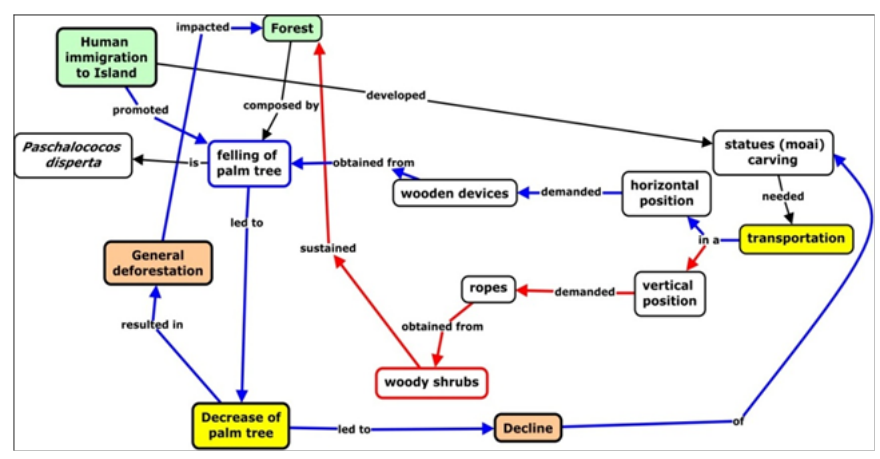

Figure 5 Focus on the part of the concept map relative to the statues transportation.

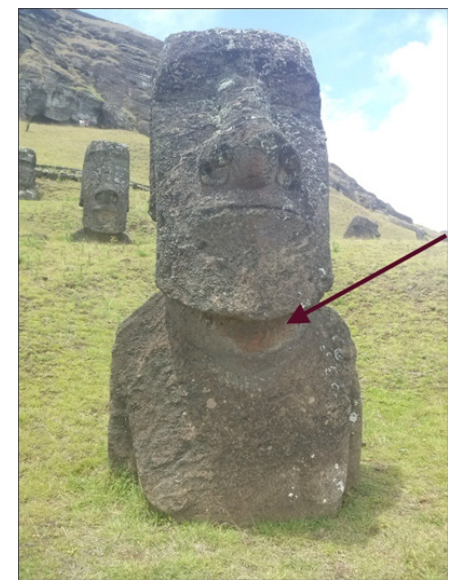

Figure 6 Rope marks on the moai neck, addressed by a native Rapanui during field trip in 2015. According to this person, these marks helps to sustain the theory of "walking statues". Photograph by Carlos Hiroo Saito (November 2015). 
The other justification for palm tree cutting by natives was the necessity to produce canoes for fishing at the sea. This was also questioned by Rosalind L Hunter Anderson ${ }^{29}$ who said that palm tree was not a good wood for this purpose. ${ }^{29}$ She said that it is dubious that the Rapanui felled the native palms to provide lumber for making canoes, because palm wood is generally avoided for building canoes according to Pacific ethnographic records. Additionally, based on Robert E Gurley \& William Liller, ${ }^{43}$ she indicated that the tough outer bark of Jubaea chilensis (similar to Rapa Nui palm) is extremely hard and very thin which would make it impossible to shape the logs by adzing and canoe would quickly break up in the ocean. That is why she said that Pacific ethnographic records indicated that the preferred wood for canoes production is from dicotyledonous trees, such as breadfruit (Artocarpus altilis) and mahogany (Calophyllum inophyllum) (Figure 7).

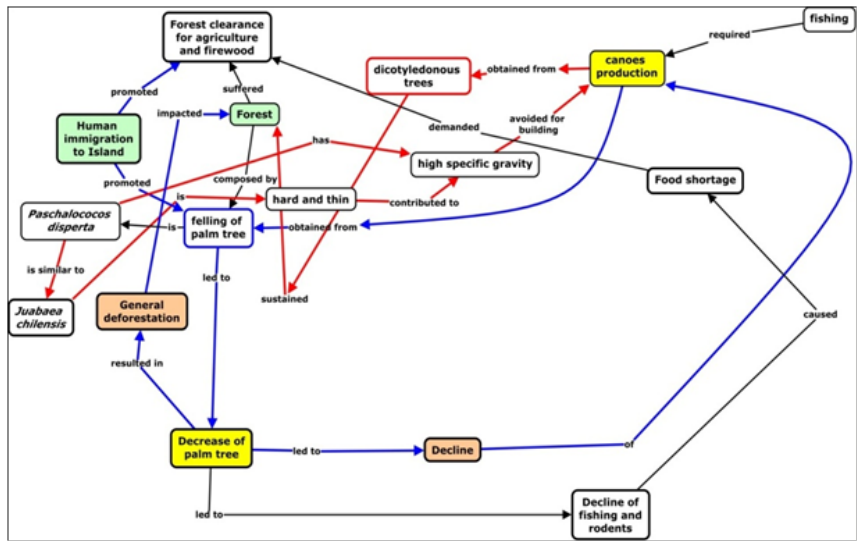

Figure 7 Focus on the part of the concept map relative to the canoes production.

From the ecocide point of view, several questions were raised about a possible lack of diagnosis and misunderstanding of the reality by the natives. ${ }^{21}$ For the counter-argument view, one of the central category of analysis is the genocide perpetrated by Europeans upon their arrival on the island ${ }^{33}$ (Figure 8). Alternatively, it has been argued in favor of a lack of alternatives among the natives: even when people realized the consequences of deforestation, each actor individually opted to advance tree cutting aiming to get a short term advantage relative to competitors. ${ }^{23}$

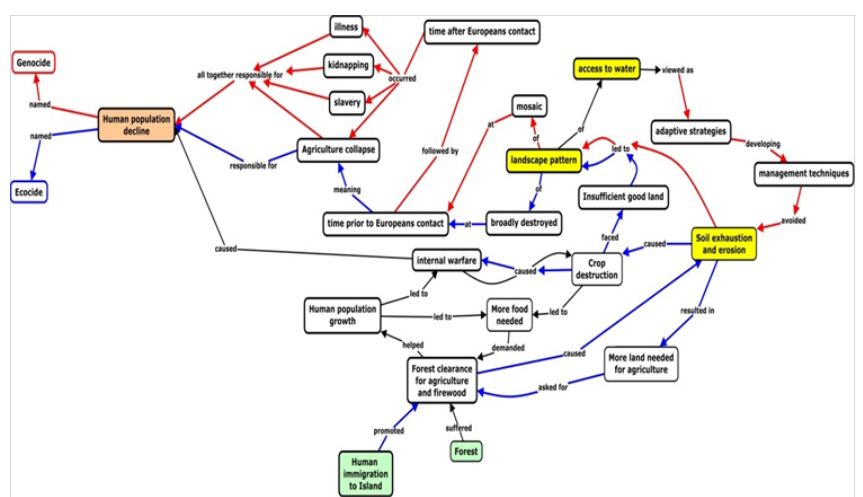

Figure 8 Focus on the part of the concept map relative to ecocide vs. genocide conceptions.

An alternative path is proposed by Christopher Stevenson and colleagues, who proposed the presence of a mosaic of different levels of food production in the Island and that although there have been declines; there was no ecological or agricultural collapse before the arrival of Europeans on the island. ${ }^{9}$ Mara A Mulrooney ${ }^{52}$ and colleagues also reached the same conclusion when presenting data on land use in Hanga Ho'onu during the period between 1700 and 1759 CE..$^{52}$ They said they found records of a slight decline in land use activity during this period, followed by a dramatic decline between 1750 and 1799 CE. They also addressed that many of the areas previously occupied were abandoned between 1800 and $1849 \mathrm{CE}$, with a complete abandonment of the entire area after 1850. According to these authors such findings do not corroborate the idea of a preEuropean collapse.

Hunter-Anderson ${ }^{29}$ added another element to reinforce an alternative explanatory path: the occurrence of the Little Ice Age between the years 1350 and $1800 \mathrm{CE}$ that would have submitted the island to a prolonged drought event and this may have contributed to the decrease of the palm trees. ${ }^{29}$ These alternative paths are also portrayed in the concept map (Figure 2) and in their essence they result in a direct opposition to the theory of ecocide.

In a closer, detailed look at the processes (Figures 3-6) in all of them it is possible to see several turning points (yellow boxes), from which it is possible to follow one route or another (a dominant view or counter-argument view), represented by blue lines or red lines, respectively. These turning points highlighted in the concept map were eating palm fruits by rodents, decrease of palm trees, transportation of statues (moai) and production of canoes, getting firewood and landscape pattern. It can be noted that red routes have in general an end termination which cannot positively feedback onto the cycle. Differently, blue routes have a cyclic path with positive feedback to increase the collapse by the decline of palm woodland. Both the dominant idea and the alternative paths are highlighted and chained portrayed in such a way that each of them can be comprehended in its completeness in the concept map.

\section{Conclusion}

As can be seen, the concept map clearly shows the conceptual logic involved in the argumentation of each perspective for the prehistory of Rapa Nui, both the dominant view and the counter-argument view. The concept map was also able to emphasize the specific relationships between the cycles of social and environmental processes, such as the conflicts between invasive alien species and native species and the specific relationship between the Pacific rat and the island of Rapa Nui. Additionally, one could see how the palm tree is connected to the supply of wood and it was possible to understand the different uses of this resource and its importance in the social and economic life of the natives. By paying attention to some cyclical processes, especially the feedback mechanisms within these cycles, it is possible to understand, in a systemic way, the impact of actions triggering these processes. Another innovative aspect in the present case is the possibility that the concept map offered to portray the confrontation between opposing or conflicting visions (the theory of the ecocide and the genocide), showing the argumentative logic of each of them and in which aspect of the chain of processes they diverge. In this way, the concept map contributes to a more comprehensive understanding of the subject and allows us to identify the key processes that will direct the interpretive choices to one school of thoughts or another. That is, it will be in these key processes that the investigations must focus to make science advance as to the best understanding of the Rapa Nui prehistory. 


\section{Acknowledgments}

I thank a lot to Valeria Pakarati, native Rapanui who gently showed me her perspective of Rapa Nui history and guided me on the Island. I also thanks to Foundation for Research Support of the Distrito Federal (FAPDF) and the Brazilian National Council for Technological and Scientific Development (CNPq) for financial support to this research.

\section{Conflict of interest}

Author declares there is no conflict of interest in publishing the article.

\section{References}

1. Heemskerk M, Wilson K, Zuckerman PM. Conceptual models as tools for communication across disciplines. Conservation Ecology. 2003;7(3):8.

2. Novak JD, Cañas AJ. Theoretical origins of concept maps, how to construct them and uses in education. Reflecting Education. 2007;3(1):29-42.

3. Primo RMA, Shavelson RJ. Problems and issues in the use of concept maps in science assessment. Journal of Research in Science Teaching. 1996;33(6):569-600.

4. Daley BJ. Using concept maps in qualitative research. In: Cañas AJ, et al. editor. Concept Maps: Theory, Methodology, Technology. Proceedings of the First Int. Conference on Concept Mapping. Pamplona, Spain; 2004.

5. Saito CH. Concept Map for Environmental Education Planning: Capacitation of Volunteers for the FIFA Football World Cup in Brazil. Journal of Education for Sustainable Development. 2016;10(2):289-308.

6. Perry GLW. Landscape, space and equilibrium: shifting viewpoints. Progress in Physical Geography. 2002;26(3):339-359.

7. Vezzoli L, Acocella V. Easter Island, SE Pacific: An end-member type of hotspot volcanism. Geol Soc Am Bull. 2009;121(5-6):869-886.

8. Ryn ZJ, Ciszewski A, Paulo A, Sobczyk M. The underground world of Easter Island - Polish exploration 2001-2008. In: Z Mirek, et al. editor. The nature and culture of Latin America. Review of Polish Studies. W Szafer Institue of Botany, Polish Academy of Science, Poland; 2010. p. $135-160$.

9. Stevenson CM, Puleston CO, Vitousek PM, et al. Variation in Rapa Nui (Easter Island) land use indicates production and population peaks prior to European contact. Proc Natl Acad Sci USA. 2015;112(4):1025-1030.

10. Junk C, Claussen M. Simulated climate variability in the region of Rapa Nui during the last millennium. Climate of the Past. 2011;7(2):579-586.

11. Gossen C, Stevenson C. Prehistoric solar innovation and water management on Rapa Nui. 2005;1-6.

12. Hamilton S. Rapa Nui (Easter Island)'s Stone Worlds. Archaeology International. 2013;16:96-109.

13. Mieth A, Bork HR. History, origin and extent of soil erosion on Easter Island (Rapa Nui). Catena. 2005;63(2):244-260.

14. Routledge KP. The Mystery of Easter island: the story of an expedition. Hazell, Watson and Viney, UK; 1919. p. 576.

15. Hunt TL, Lipo CP. Late colonization of Easter Island. Science. 2006;311(5767):1603-1606.

16. Flenley JR, Bahn PG. Conflicting view of Easter Island. Rapa Nui Journal. 2007;21(1):11-13.

17. Flenley JR, King ASM, Jackson J, et al. The Late Quaternary vegetational and climatic history of Easter Island. Journal of Quaternary Science. $1991 ; 6(2): 85-115$
18. Ramirez JM. Historia de Rapa Nui. In: Marambio P, editor. Rapa Nui: passado, presente, future, Oficina Regional de Educación para America Latina y el Caribe-OREALC/UNESCO, USA; 2011. p. 11-31.

19. Mieth A, Bork HR. Humans, climate or introduced rats-which is to blame for the woodland destruction on prehistoric Rapa Nui (Easter Island)? Journal of Archaeological Science. 2009;37(2):417-426.

20. Orliac C. Données nouvelles sur la composition de la flore de l'île de Pâques. Journal de la Société des Océanistes. 1998;107(2):135-143.

21. Diamond JM. Collapse: How Societies Choose to Fail or Succeed. Penguin Books, London, UK; 2005. p. 1-571.

22. Bahn PG, Flenley J. Easter Island, Earth Island. Thames and Hudson, London, UK; 1992.

23. Pakandam B. Why Easter Island collapsed: an answer for an enduring question. Economic History Working Papers, 117/09. Department of Economic History, London School of Economics and Political Science, London, UK; 2009. p. 1-53.

24. Flenley J, Bahn PG. The Enigmas of Easter Island: Island on the Edge. Oxford University Press, New York, USA; 2003. p. 274.

25. Diamond JM. Rats as agents of extermination. Nature. 1985;318(6047):602-603.

26. Jones HP, Tershy BR, Zavaleta ES, et al. Severity of the effects of invasive rats on seabirds: a global review. Conserv Biol. 2008;22(1):16-26.

27. Bork HR, Mieth A. The key role of Jubaea palm trees in the history of Rapa Nui: a provocative interpretation. Rapa Nui Journal. 2003;17(2):119-122.

28. Horrocks M, Wozniak JA. Plant microfossil analysis reveals disturbed forest and a mixed-crop, dryland production system at Te Niu, Easter Island. Journal of Archaeological Science. 2008;35(1):126-142.

29. Anderson RLH. Human Vs. Climatic Impacts at Rapa Nui: Did the People Really Cut Down All Those Trees? In: CM Stevenson, et al. editor. Easter Island in Pacific Context; South Seas Symposium: Proceedings of the Fourth International Conference on Easter Island and East Polynesia. Los Osos the Easter Island Foundation, USA; 1998. p. 85-99.

30. Huebert JM, Allen MS, Wallace RT. Polynesian earth ovens and their fuels: Wood charcoal remains from Anaho Valley, Nuku Hiva, Marquesas Islands. Journal of the Polynesian Society. 2010;119(1):61-98.

31. Orliac C. The woody vegetation of Easter Island between the early 14th and the mid-17th centuries A.D. In: WS Ayres, editor. Easter Island Archaeology: Research on Early Rapanui Culture. Easter Island Foundation and Cloudmountain Press, USA; 2000. p. 211-220.

32. Mann D, Edwards J, ChaseJ, et al. Drought, vegetation change, and human history on Rapa Nui (Isla de Pascua, Easter Island). Quaternary Research. 2008;69(1):16-28.

33. Peiser B. From genocide to ecocide: the rape of Rapa Nui. Energy \& Environment. 2005;16(3):513-539.

34. Hunt TL, Lipo CP. The statues that walked: unraveling the mystery of Easter Island. Free Press, New York, USA; 2011. p. 256.

35. Hito S. Vaai Hanga Kainga: giving care to the motherland: conflicting narratives of Rapanui. Journal of Intercultural Studies. 2004;25(1):21-34.

36. Folledo M. Raciocínio Sistêmico: uma boa forma de se pensar o meio ambiente. Ambiente \& Sociedade. 2000;6(7):105-145.

37. Monat JP, Gannon TF. What is systems thinking? a review of selected literature plus recommendations. American Journal of Systems Science. 2015;4(1):11-26.

38. Grau J Jubaea. The palm of chile and Easter Island? Rapa Nui Journal. 1996;10(2):37-40. 
39. Hunt TL, Lipo CP. Chronology, deforestation and collapse: evidence vs. faith in Rapa Nui prehistory. Rapa Nui Journal. 2007;21(2):85-97.

40. Gonzalez LA, Bustamante RO, Navarro CRM, et al. Ecology and management of the chilean palm (Jubaea chilensis): history, current situation and perspectives. Palms. 2009;53(2):68-74.

41. Simonetti F. Stem Tapering in Jubaea chilensis. Palms 2006;50(3):109-110.

42. Phil Markey. Paschalococos disperta The Extinct Palm from Easter Island. Trebrown Nurseries, USA; 2009.

43. Gurley RE, Liller W. Palm Trees, Mana, and the Moving of the Moai. Rapa Nui Journal. 1997;11(2):82-84.

44. Gossen CL, Stevenson C. Prehistoric Solar Innovation and Water Management on Rapa Nui. International Solar Energy Society (ISES)/American Solar Energy Society (ASES) Conference Proceedings, Solar World Congress, USA; 2005. p. 2580-2585.

45. Wozniak JA. Prehistoric horticultural practices on Easter Island: lithic mulched gardens and field systems. Rapa Nui Journal. 1999;13(3):95-99.

46. Lightfoot DR. Morphology and ecology of lithic-mulch agriculture. The Geographical Review. 1994;84(2):172-185.
47. Metraux A. Ethnology of Easter Island (Bulletin 160). Honolulu: Bernie P Bishop Museum Press. USA; 1940.

48. Vogt B, Moser J. Ancient rapanui water management: german archaeological investigations in Ava Ranga Uka a Toroke Hau, 2008-2010. Rapa Nui Journal. 2010;24(2):18-26.

49. Meyer JY. Rapport de mission d'expertise a Rapa Nui du 02 au 11 Juin 2008: Plan d'action strategique pour lutter contre les plantes introduites envahissantes sur Rapa Nui (Île de Pâques). Papeete, Tahiti: Délégation à la Recherche, Ministère de l'Education, l'Enseignement supérieur et la Recherche, USA; 2008. p. 1-64.

50. Overholt KJ, Cabrera J, Kurzawski A, et al. Characterization of fuel properties and fire spread rates for little bluestem grass. Fire Technology. 2014;50(1):9-38.

51. Lipo CP, Hunt TL, Haoa SR. The 'Walking' Megalithic Statues (Moai) of Easter Island. Journal of Archaeological Science. 2013;40(6):2859-2866.

52. Mulrooney MA, Ladefoged TN, Stevenson CM, et al. The myth of A.D. 1680: new evidence from Hanga Ho’Onu, Rapa Nui (Easter Island). Rapa Nui Journal. 2009;23(2):94-105. 